\title{
Religiões, Escola, Livros Para Crianças e Jovens
}

\author{
Religions, school, books for children and young people
}

Regina Zilberman*

*Universidade Federal do Rio Grande do Sul, Instituto de Letras. Av. Bento Gonçalves 9500, Agronomia, 91540-000 - Porto Alegre, RS - Brasil. e-mail: regina.zilberman@gmail.com

RESUMO: Conflitos religiosos têm se mostrado frequentes na história moderna em razão de discordâncias teológicas e de disputas territoriais. Por outro lado, cada religião dispõe de rico acervo cultural, que se transmite por intermédio da escola e da literatura. A literatura infantil beneficia-se dessa herança cultural, como exemplificam os autores estudados.

PALAVRAS-CHAVE: Religião; Escola; Literatura Infantil.

ABSTRACT: Religious conflicts have been frequent in modern history because of theological disagreements and territorial disputes. On the other hand, each religion has a rich cultural heritage, which is transmitted through school and literature. Children's literature benefits from this cultural heritage, as exemplified by the authors studied.

KEYWORDS: Religion; School; Children's Literature.

Vovó disse que tem uma coisa que chama preconceito, que a gente precisa saber vencer ele. Confesso que não entendi nada. Para mim todo mundo é irmão. E irmão tem que cuidar de irmão, tem que respeitar, tem que deixar ser feliz. É assim na natureza. Seria bom que fosse assim também entre as pessoas. Daniel Munduruku (2014, p. 12)

\section{RELIGIÃO, RELIGIÕES}

No último livro que publicou em vida, Moisés e o monoteísmo, de 1939, Sigmund Freud expôs sua tese sobre a origem do monoteísmo e da religião hebraica. Lembra que o primeiro culto monoteísta nasceu no Egito, à época do faraó Aquenáton, no século XIV a. C. Denominado inicialmente Amenófis IV, ele fez questão de alterar sua identidade ao in- 
troduzir a aceitação de Aton como deus único, substituindo o até então vigente politeísmo entre seu povo.

A veneração a Aton, ou o Sol, durou enquanto Aquenáton esteve vivo, restaurandose o politeísmo logo após sua morte. Mas, segundo Freud, aquele culto não desapareceu, mantendo-se entre alguns seguidores, entre os quais o aristocrata depois conhecido, entre os hebreus, como Moisés. Este, inconformado com a perseguição à crença que abraçara, encontrou adeptos possíveis entre os escravos provenientes de Canaã, desde que liderasse o retorno deles à sua terra natal. É a esse grupo que Moisés impõe o monoteísmo, mas não de modo pacífico: os agora ex-escravos revoltam-se contra o comandante autoritário, matando-o, e retornam, por um tempo, aos rituais politeístas.

Freud cogita que essa regressão não durou muito: o povo hebreu, sentindo-se culpado pela morte de seu líder, retoma os ideais monoteístas, ainda que não adote Aton como seu deus. Esse é agora Jeová, uma divindade tão autoritária quanto o extinto Moisés, implacável e repressora, mas que prescreve uma legislação ao povo de Canaã, calcada, de um lado, na obediência, de outro, na ética e na espiritualidade. ${ }^{1}$

Pode-se não aceitar o mito de origem proposto por Sigmund Freud, que, em Moisés e o monoteísmo, dá sequência à sua visão do modo como a civilização se impõe entre os seres humanos: há, no começo, um crime contra a autoridade - paterna, em Totem e tabu, política, em Moisés e o monoteísmo - de que advêm a culpa e o trauma. Esses permanecem latentes por algum tempo, mas, depois, emergem, cobrando a dívida, paga por meio da divinização daquele que foi objeto da ação violenta e destrutiva de um indivíduo ou do grupo. Civilização e coerção são quase sinônimos no universo descrito por Freud, sendo uma de seus expressões o culto religioso monoteísta. ${ }^{2}$

Mesmo que não se concorde com a hipótese de Freud relativamente à origem do monoteísmo hebraico, é preciso convir que o diagnóstico daquele autor é certeiro na maioria dos aspectos que aponta. Em primeiro lugar, identifica que o monoteísmo não sucedeu ao politeísmo, como se aquela crença fosse superior a essa. Além disso, historiciza seu aparecimento, que teria começado por volta do século XIV a. C., portanto há 3500 anos. E

\footnotetext{
${ }^{1}$ Cf. FREUD, 2001; ASSMANN, 1998; BERNSTEIN, 2000; YERUSHALMI, 1996.

${ }^{2}$ Cf. FREUD, 1970; FREUD, 1996; FREUD, 1996a.

Volume 17

Número 36
} 
chama a atenção para a subsequente simultaneidade entre as duas principais maneiras de conceber as divindades.

Em segundo lugar, sugere o caráter mais liberal do politeísmo, que se mostra habilitado a absorver crenças de outros povos ou culturas, enquanto que o monoteísmo, por sua natureza, se entende único e indiscutível. Pode-se, no máximo, substituir a fé em Jeová pela fé em Alá, mas os dois deuses não podem conviver sob o teto de uma mesma religião. Esses confrontos sucederam-se ao longo da história, desde que os monoteísmos se implantaram no Ocidente, opondo primeiramente Judaísmo e Cristianismo, mais adiante, Cristianismo e Islamismo, disputa agudizada em nossos dias. Da sua parte, as religiões politeístas prosseguem sua tendência à incorporação de entidades divinas de crenças distantes, a exemplo do que ocorreu no Brasil, desde os tempos coloniais, quando santos e figuras sagradas do panteão cristão foram apropriadas ou identificadas aos deuses e aos rituais trazidos pelos africanos escravizados pelos portugueses.

Freud reconhece ainda um terceiro atributo do monoteísmo, nascido com o judaísmo: a tendência à espiritualização, com a identificação de valores de natureza ética aos quais compete pautar o comportamento dos seres humanos. Esse aspecto não é necessariamente positivo, se lembramos que decorre de um sentimento de culpa, compensado, no Cristianismo, pela aspiração à redenção. Por outro lado, ele incide na possibilidade de uma reflexão filosófica, razão por que pôde dar nascimento a vertentes da filosofia e a uma teologia, expressadas por pensadores como Santo Agostinho, Abelardo ou Santo Tomás de Aquino, atuantes no período medieval, ou Paul Tillich e Teilhard de Chardin no século XX.

Contemporaneamente, são três as principais correntes monoteístas: o Judaísmo, o Cristianismo e o Islamismo. Independentemente de suas diferenças, e das divisões do Cristianismo nas vertentes católica, ortodoxa e protestante, verificam-se nessas correntes uma certeza indiscutível: a crença em um Deus único e onipotente, ainda que ele possa responder a denominações distintas (Elohim, Adonai, Jeová, ou Javé, para os judeus; Espírito Santo ou Nosso Senhor, para os cristãos; Alá para os muçulmanos). Também monoteístas são o zoroastrismo e a fé Bahá'í, ambas nascidas na Pérsia da Antiguidade.

Os politeísmos são bem mais numerosos, encontrando-se expressões suas em todas as regiões do planeta. Datam dos primeiros tempos da humanidade, quando à natureza, tida como ameaçadora, eram conferidas qualidades mágicas. Em outro momento da história, a esses atributos foram concedidos nomes ou forma humana, como ocorre entre os gregos, Volume 17 Número 36 
em que Zeus corresponde aos céus ou a fenômenos como os raios e ao trovão, Apolo à luz e ao sol, Poseidon aos mares. As ações protagonizadas por essas figuras deram nascimento a narrativas conhecidas como mitos, fomentando a poesia, as artes plásticas e, entre os helênicos, até a filosofia.

Entre alguns povos, o monoteísmo substituiu o politeísmo: os latinos, que na Antiguidade construíam templos para seus deuses, como Júpiter ou Vênus, ou cultivavam-nos em suas casas, em altares domésticos, tornaram-se, em grande parte, adeptos do Cristianismo, após a conversão do imperador Constantino e a instalação plena da Igreja em Roma. Mas o Budismo, adotado principalmente em países asiáticos e que conta com fiéis em outros continentes, soma cerca de 350 milhões de adeptos, correspondente a $6 \%$ da população mundial. Outras crenças politeístas são o Bramanismo, o Candomblé, o Confucionismo, o Hinduismo, o Taoísmo e a Umbanda.

\section{A PERSEGUIÇÃO RELIGIOSA}

Não se contata, entre os povos da Antiguidade, conflitos de ordem religiosa. Parece improvável que a destruição do primeiro templo de Jerusalém, no século VI a. C., pelos exércitos comandados por Nabucodonosor, e o consequente exílio dos hebreus na Babilônia, lamentado pelo profeta Jeremias, fossem provocados por motivos religiosos. Por sua vez, a destruição do segundo templo, por Tito, no século I d. C., a que se seguiu nova dispersão dos judeus, deveu-se ao imperialismo romano.

É entre os seguidores originais do nazareno Jesus que se encontram provavelmente os primeiros movimentos de perseguição a pessoas, grupos ou povos por divergências religiosas. Até a conversão do imperador romano Constantino, em 312, os cristãos eram obrigados a cultuar seu Deus de modo clandestino, sendo as catacumbas uma das reminiscências desse período. Com a mudança de ordem política, e a instalação do Papado em Roma, no século IV, o Cristianismo tornou-se religião oficial e procurou ampliar seus domínios sobretudo pela catequese. Assim, ainda que o império romano tenha-se esfacelado após as invasões dos povos chamados bárbaros, como eram qualificados anglos, francos, saxões, suevos, visigodos, vândalos, entre outros, ele não perdeu inteiramente a hegemonia ideológica, linguística e até cultural graças à adoção, quase generalizada, da religião monoteísta emanada da sede latina.

Evidencia-se, desde esses tempos, uma associação entre expansão imperialista e imposição religiosa. Quando, no século VIII, os árabes, agora muçulmanos por influência de Volume 17

Número 36 
seu profeta Maomé, ocuparam o norte da África e boa parte da Europa banhada pelo Mediterrâneo, ainda não se tratava de uma guerra religiosa. Porém, as Cruzadas, entre os século XI e XIV, justificaram-se ideologicamente, porque correspondiam à hipótese de retomar Jerusalém, a cidade sagrada e berço do Cristianismo, das mãos dos considerados hereges. A Reconquista, nome que tomou a reintegração de posse da Península Ibérica pelos descendentes dos visigodos, tinha igualmente o intuito de afastar os seguidores de Maomé e eliminar suas marcas culturais que se enraizaram ao longo dos séculos em que eles habitaram a região.

A religião enquanto máscara para a ação imperialista torna-a problemática, de um lado, pelo caráter predatório resultante da vitória de um segmento sobre o outro. Exemplo disso é a colonização da América, desde o século XVI, justificada em parte porque se tratava de catequizar os povos que viviam naquela região, distantes das possibilidades da salvação a não ser por meio da adoção da fé cristã. Em nome desse princípio, foram induzidos, pela força do discurso, mas também pela violência, a incorporar uma escrita que não era sua, bem como hábitos e ideias com os quais podiam não se identificar. ${ }^{3}$ De outro lado, ela é igualmente problemática, porque incide numa perspectiva irracionalista e desumana, segundo a qual a fé legitima o ato mais cruel, já que o adversário é desprovido de humanidade, encarado como um objeto ou indivíduo selvagem, predicado atribuído àqueles com os quais a pessoa tomada pela crença religiosa avalia o outro.

O irracionalismo e a barbárie, quando resultam de crenças inabaláveis e indiscutíveis, podem estar presentes mesmo em grupos tidos como civilizados, responsáveis por culturas julgadas superiores. O século XX presenciou atos decorrentes do fanatismo, nem sempre religioso, mas invariavelmente partidário, e o século XXI experimenta de modo direto ou indireto, vivenciando ou testemunhando-a, a continuidade de um processo lamentável.

Outro fator que determina, com alguma frequência, a perseguição religiosa - ou política, em situações similares - e deriva do antes exposto, é o dogmatismo que acompanha as seitas e as confissões de fé. O dogmatismo consiste em uma série de afirmações que não podem - nem devem - ser questionadas, mesmo porque carecem de uma explicação racional ou científica. Dogma indiscutível dos monoteísmos mais difundidos é, por exemplo, a

\footnotetext{
${ }^{3}$ Cf. MiGnOLO, 1998. RIBEIRO, 1980.
}

Volume 17

Número 36 
afirmação de que a única divindade legítima é a da própria fé, impedindo, assim, qualquer aproximação ou assimilação entre Deus, Jeová ou Alá.

Dessa asserção advém o conflito, ao lado do empenho de estabelecer a supremacia de uma crença sobre outra, o que pode se efetivar pela doutrinação. As crenças religiosas não dependem, pois, apenas da fé e da aceitação, mas também pela imposição de certos valores e ideias. Quando essas são rejeitadas ou discutidas, a alternativa é a criminalização da dissidência, o que, ao longo da história, deu-se por meio de instrumentos como a catequese, de que foram alvo os nativos da América entre os séculos XVI e XIX, ou a Inquisição, que se estendeu do século XII ao XIX, na Europa, com extensões em regiões, na América, onde vigiam as leis das nações colonizadoras, como Espanha, Portugal e Inglaterra.

Toda religião dispõe de uma visão de mundo e de uma teoria da história da humanidade, que se estende da criação até, eventualmente, sua extinção, que pode coincidir com um apocalipse ou uma redenção. Conta também com uma filosofia, traduzida em uma concepção da divindade que a conduz, em valores éticos e de conduta, e, seguidamente, em promessas de futuro, que pode ser, por exemplo, a recuperação do Paraíso ou a chegada ao nirvana. Proceder corretamente e fazer o bem, beneficiando a coletividade, parece importar para a maioria das religiões, e esse aspecto aparentemente justifica sua existência; mas elas incidem também na obediência e no controle social, o que pode torná-las problemáticas ou polêmicas.

As dificuldades se agravam quando representantes de uma religião querem obrigá-la sobre os demais, utilizando para tanto a violência da doutrinação ou das armas. Mais trágico, quando, ao lado da imposição doutrinária pela violência, a religião serve de pretexto para a dominação imperialista de um povo sobre o outro. Apresentam-se então as formas de perseguição a que se assiste há alguns séculos, configurando o ângulo agudo e penoso da relação dos distintos grupos humanos e das diferentes pessoas com as crenças religiosas.

\section{RELIGIÃO E LITERATURA}

Religiões são crenças que se transmitem por meio de doutrinas, de uma parte, de outra, por intermédio de histórias que comprovam as principais ideias em que se fundamentam. Por isso, deram origem a obras que se tornaram exemplares. Os credos monoteístas dispõem de seus livros basilares: os judeus, a Bíblia hebraica ou Velho Testamento, dividido em três grandes partes: Pentateuco ou Torá, Profetas e Escritos; os cristãos, a Bíblia cristã ou Novo Testamento, formada pelos Evangelhos atribuídos a Marcos, João, Mateus e Volume 17 Número 36 
Lucas, os Atos dos Apóstolos, as Epístolas e o profético Apocalipse; os muçulmanos, o Corão, repartido em trinta partes iguais, chamadas de juz, em árabe.

Todos mesclam narrativas com assertivas doutrinárias, procurando incutir em seus seguidores os princípios fundamentais da fé. Também normas e prescrições são expostas por essas obras, definindo o comportamento dos fiéis, os valores a preservar e as punições que recaem sobre aqueles que contrariam os mandamentos provenientes de Deus e enunciados por seus principais profetas, como Moisés, entre os judeus, ou Maomé, entre os islâmicos.

As religiões politeístas também contaram com seus livros sagrados. Dentro desse universo, muitos estudiosos incluem as epopeias, Ilíada e Odisseia, atribuídas a Homero. Porém, com mais propriedade, podem ser considerados produtos religiosos os Vedas, dos indianos, os Upanishads, entre os brâmanes, o Ramayana e o Mahabharata, do qual faz parte o Bhagavad-gita, entre os hinduístas.

Nessas, e em outras obras associadas a cultos religiosos, estão presentes narrativas que se aproximam do gênero épico. Muitas apresentam eventos fundadores - a formação do universo, como no Gênesis, primeiro livro do Pentateuco, que abre a Bíblia hebraica. Mostram também a ação de personagens dotados de qualidades guerreiras, aptidões para a liderança ou capacidade profética, virtudes que se encontram, por exemplo, em Josué, Jesus ou Elias. O oriental Bhagavad-gita relata o diálogo de Krishna com Arjuna, seu discípulo, antes da batalha decisiva entre Pandavas e Kauravas. O Ramayana, por sua vez, conta a história do príncipe Rama, encarnação do deus Vixnu, responsável pela manutenção do universo. Essas obras fundadoras ainda indicam a sorte daqueles que desobedeceram os preceitos estabelecidos pela fé, como o casal primordial Adão e Eva, na Bíblia hebraica, ou traíram companheiros, como Judas, nos evangelhos que compõem a Bíblia cristã.

Com o intuito ou não de comprovar regras previamente estabelecidas, o fato é que as obras religiosas povoam nosso imaginário com histórias ricas de ação, protagonizadas por figuras que sintetizam o comportamento humano na sua diversidade e possibilidade. Fomentam, assim, formas de expressão que ultrapassam suas origens, dando margem à manifestação artística - literária, quando predomina o uso da enunciação verbal; mas também plástica, musical ou performática, quando são escolhidas outras modalidades de linguagem, como a da imagem, do som ou do corpo. 


\section{LETRAS}

Em tais casos, o credo religioso pode estar presente, mas não é o único objetivo da obra resultante da apropriação dos motivos originalmente presentes em livros sagrados. A escultura em que o Michelangelo representa Moisés, a pintura em que Leonardo da Vinci expõe a Santa Ceia, o poema em que Dante Alighieri conta como foi guiado por Virgílio no Inferno, a epopeia em que John Milton relata a rebeldia de Lúcifer e a perda do Paraíso por Adão e Eva, são obras devedoras das narrativas difundidas nas Bíblias hebraica e cristã. Mas correspondem também a criações em que a genialidade de seus autores foi capaz de evidenciar não a santidade de cada um dos figurantes, mas a humanidade que os aproxima de todos nós e com os quais nos identificamos enquanto pessoas.

Crenças religiosas podem ser pretextos para perseguir, pregar, dizimar e condenar, quando praticadas de modo dogmático, intransigente e intolerante. Mas suas expressões em textos sagrados podem estimular a exposição de criaturas complexas e de situações problemáticas, facultando a seus destinatários entender as próprias dificuldades e alternativas de ação. Tornam-se, assim, parte do patrimônio artístico da humanidade, ao qual pertence, com legitimidade, a literatura dirigida a crianças e jovens.

\section{RELIGIÃO E LITERATURA PARA CRIANÇAS E JOVENS}

Crianças e jovens são introduzidos à religião por vários meios. Ao nascerem, podem ser alvo de rituais que as vinculam a uma seita: entre os cristãos, o batismo tem essa função, assim como a circuncisão entre os judeus. A transmissão das narrativas sagradas constituem igualmente uma maneira de ingresso aos valores e concepções que aquelas histórias transmitem. Essas narrações podem ocorrer no ambiente doméstico ou em espaços públicos consagrados, como uma igreja, uma sinagoga ou uma mesquita. Mas elas podem acontecer também no âmbito das escolas, desde que as autoridades educacionais e políticas concordem em que é importante oferecer uma formação religiosa à infância e à juventude.

No Brasil, a educação religiosa vigorou desde o começo da colonização portuguesa, pois os primeiros administradores do território português no Novo Mundo chegaram acompanhados de jesuítas, encarregados de catequizar os habitantes nativos da região, a que denominaram indígenas. Também foram criadas escolas para os filhos dos colonizadores provenientes de Portugal ou já nascidos no Brasil. Em ambos os casos, essa formação era cató- 
lica, excluindo tanto as crenças dos indígenas, como as dos brasileiros descendentes dos europeus que não fossem cristãos.

A escolarização, contudo, somente se institucionaliza no século XIX, quando o Brasil conquista autonomia política diante de Portugal. Mantém-se o princípio da transmissão da confissão católica romana e, como aumenta o número de estudantes, dado o crescimento da população, começam a ser publicados livros que, destinados a essa faixa etária, comunicam conteúdos religiosos. Esses livros podem ser repartidos em dois grandes grupos, que espelham as tendências da literatura dirigida à infância e mocidade que se compromete com o ensinamento cristão, já que fés de inclinação distinta permanecem excluídas ou ignoradas.

O primeiro desses dois grupos é formado pelos catecismos; o segundo, pelas adaptações dos livros sagrados, sobretudo da Bíblia. No século XIX brasileiro, o cônego Joaquim Caetano Fernandes Pinheiro escreveu obras conforme cada um desses modelos: é autor de um Catecismo de doutrina cristã, sumariando preceitos relativos à crença abraçada pelo Estado, e de uma História sagrada, com episódios extraídos do Velho e do Novo Testamento. Os dois livros foram adquiridos pelo governo para distribuição gratuita em escolas, ${ }^{4}$ sintoma de que o poder executivo interferia na educação religiosa dos brasileirinhos. Outra obra de larga circulação no ensino nacional foi o Catecismo histórico, do parisiense Claude Fleury (1640-1723), que também circulou em tradução entre estudantes, conforme diagnostica Gonçalves Dias em relatório enviado ao imperador Pedro II, em 1862. ${ }^{5}$

Atualmente, obras de conteúdo religioso continuam a ser oferecidas nesses dois formatos. O Catecismo abreviado visa à "catequese para Primeira Eucaristia", conforme se apresenta na home page da editora Vozes. ${ }^{6}$ Por sua vez, o Catecismo do umbandista sugere que o gênero adequa-se facilmente a outras seitas. Da sua parte, Bíblias para crianças são assíduas em catálogos de editoras, a exemplo da Histórias da Bíblia Sagrada para crianças, de 2014.

Não apenas narrativas extraídas dos livros sagrados caracterizam a produção destinada à infância e juventude. Vidas de santos adaptadas à leitura de crianças e jovens ainda

\footnotetext{
${ }^{4}$ Cf. TAMBARA, Elomar. Livros de leitura nas escolas de ensino primário no século XIX no Brasil.

${ }^{5}$ O Relatório de Gonçalves Dias está reproduzido em: MOACYR, Primitivo. 1939, V. 2. p. 525-526. 6

http://www.universovozes.com.br/livrariavozes/web/view/DetalheProdutoCommerce.aspx?ProdId=85326046 84. Acesso em: 17 nov. 2015. 
são frequentes, a que se somam as histórias de descoberta da vocação religiosa. As obras do cônego Schmid (1768-1854) circulavam no Brasil desde a segunda metade do século XIX, sendo a leitura delas - especialmente A cestinha de flores - estimulada por compras governamentais e distribuição entre a população escolar (TAMBARA). Seus livros frequentaram o catálogo da Editora do Brasil até a segunda metade do século XX, circulando em escolas e lares católicos e protestantes.

Marcelino pão e vinho, do espanhol José Maria Sanchez-Silva, publicado originalmente nos anos 1950, pertence a esse grupo de textos em que se mesclam o cotidiano de crianças e personagens da história sagrada. Nessa obra de grande sucesso, haja vista que ainda figura no catálogo da editora Record, é apresentada a história de um menino órfão educado por frades franciscanos que, em escapada ao sótão do convento, encontra um Jesus na cruz com quem dialoga e a quem generosamente alimenta. O garoto representa a inocência da infância a quem o crucificado, em mais de um evangelho, diz pertencer o "reino dos Céus". Embora não se trate de um livro de formação ou doutrinação, espelha uma visão católica de mundo, que almeja ver compartilhada entre o público leitor.

Nessas obras, reconhece-se um conteúdo religioso, que se transmite por meio de uma história - extraída de textos sagrados, hagiografias ou da imaginação de um escritor e de personagens, sejam inventadas ou não. Ao lado delas, podem-se identificar outro tipo de produção dirigida à infância e à juventude que têm caráter discursivo, e não ficcional, sendo o exemplo mais notório Agapinho, de 2010, de Marcelo Rossi, versão adaptada de Ágape, em que se ajustam os ensinamentos da versão original ao leitor mirim. O livro tem teor pedagógico, ainda que não escolar, ao transmitir ideias e valores universais, traduzidos em mensagens positivas que sugerem atitudes aprováveis no âmbito da ética e da religião. Além disso, flerta com a auto-ajuda, pois, ainda que vise fortalecer convicções cristãs, o que oferece são saídas para os problemas pessoais de seus leitores. Ao afirmar, por exemplo, que "se um dia se sentir triste e sozinho, lembre-se de que há um amigo que cuida de você e nunca vai te abandonar" (ROSSI, 2012, p. 7), o sujeito do discurso supõe que o destinatário da oração entenda que o amigo é Jesus, até porque ele é mencionado na frase subsequente. Por outro lado, a lembrança só se manifestará, quando o indivíduo a quem a frase se dirige, encontrar-se deprimido e precisar de algum tipo de apoio emocional.

A literatura de conteúdo religioso dirigida a crianças e jovens, desde suas primeiras manifestações no Brasil, esteve muito próxima da escola, razão por que predominam clériVolume 17

Número 36 
gos entre os autores, como os mencionados Fernandes Pinheiro, Schmid e Marcelo Rossi. A proximidade não é ocasional: temas religiosos faziam - e ainda fazem - parte do currículo escolar. Mais significativa é a circunstância de que as religiões, sobretudo as monoteístas, supõem uma doutrina, e essa precisa ser ensinada. Com isso, o fator doutrinário migra da fé para a literatura, que se torna porta-voz daquela, perdendo sua autonomia enquanto uma manifestação própria da linguagem.

Mas talvez não precise ser necessariamente assim, se os objetivos postos sobre a literatura infantojuvenil de tema religioso ou sagrado forem outros. É o que sugerem as determinações a serem adotadas para o ensino, consignadas no documento intitulado Base Nacional Comum Curricular (BNCC), elaborado pelo Ministério de Educação. Se e quando implementadas, elas provavelmente colaborarão para que a literatura dirigida a crianças e jovens se mostre menos comprometida com o ângulo normativo, ao valorizar, na tradição religiosa, o que de mais rico ela ofereceu à humanidade: um valioso acervo de narrativas e de personagens, que podem protagonizar obras em que o compromisso com a fé que lhes deu origem passa para um segundo plano.

O documento emanado do Ministério de Educação tem como propósito oferecer coordenadas gerais que fundamentem as práticas docentes nas diferentes áreas do conhecimento nos níveis Fundamental e Médio. Seu ponto de partida, no segmento destinado ao Ensino Religioso, é o “conhecimento da diversidade religiosa” (BRASIL, 2016, p. 171), sinalizando o caráter laico da educação nacional, de uma parte, de outra, a necessidade de que as crianças tenham acesso a uma tradição de que fazem parte. Por essa razão, o documento destaca que,

O Ensino Religioso, articulado as demais áreas e componentes curriculares do Ensino Fundamental, tem como objeto de estudo o conhecimento religioso produzido no âmbito das culturas e tradições religiosas (indígenas, africanas, afro-brasileiras, judaico, cristã e islâmica, espiritas, hindus, chinesas, japonesas, semitas, movimentos místicos, esotéricos, sincréticos, entre muitos outros), e os conhecimentos não-religiosos (ateísmo, agnosticismo, materialismo, ceticismo, entre outros), assumindo a pergunta, a pesquisa e o diálogo como princípios metodológicos orientadores dos processos de observação, identificação, análise, apropriação e ressignificação dos saberes. (BRASIL, 2016, p. 172)

\section{Logo,}


Diante das perspectivas elencadas, o Ensino Religioso não pode ser concebido como ensino de uma religião ou das religiões na escola, porque busca construir, por meio do estudo dos conhecimentos religiosos e não religiosos, atitudes de reconhecimento e respeito, ao mesmo tempo em que instiga a problematização das relações entre saberes e poderes de caráter religioso, presentes no contexto social e escolar. (BRASIL, 2016, p. 173).

Sob esse ângulo, o Ensino Religioso pode ser um mecanismo de democratização do saber e redução de arestas de conflito, que constituem, como se observou, o aspecto problemático e, eventualmente, discutível da religião. Essa questão expressa-se no documento público:

[...] discriminações e preconceitos entre grupos sociais são desnaturalizados e, na medida em que são abordados como elementos de aprendizagem, contribuem para a convivência respeitosa.

A ética da alteridade é um dos fundamentos metodológicos a orientar o diálogo inter-religioso e intercultural, basilar para o reconhecimento da diversidade religiosa, implicando em co-responsabilidades para o bemviver, enquanto principio orientador de escolhas, atitudes e políticas de vida coletiva. (BRASIL, 2016, p. 173)

Portanto, o Ensino Religioso pode ser um elemento valioso para a desconstrução de preconceitos e desarme de concepções conflitantes ou dogmáticas, colaborando para o pacificação das zonas de atrito e para a convivência amistosa entre grupos humanos de confissões distintas e até opostas. A literatura infantil e juvenil pode constituir um importante aliado para que tais objetivos sejam alcançados.

\section{LIVROS PARA CRIANÇAS DE TEMÁTICA VINCULADA A RELIGIÕES}

Povos de diferente procedência formaram a população atual brasileira. Descendentes de europeus, de africanos e de orientais mesclaram-se aos grupos nativos, trazendo consigo suas culturas e crenças. Por isso, afirma-se que, Brasil, predomina a diversidade religiosa, expressão utilizada no documento relativo à Base Nacional Comum Curricular, produzido pelo Ministério da Educação. E, como o Estado é laico, não há a identificação entre o país e uma dada religião. Nesse sentido, a Constituição nacional garante 
a liberdade de consciência e de crença, sendo assegurado o livre exercício dos cultos religiosos e garantida, na forma da lei, a proteção aos locais de culto e a suas liturgias. ${ }^{7}$

Os livros dirigidos às crianças lidam com essa variedade, oferecendo textos em que, sem doutrinar ou privilegiar uma crença em detrimento de outra, predominam narrativas protagonizadas por personagens extraídas dos livros sagrados de variadas religiões.

As Histórias da Bíblia, de larga tradição na literatura e na escola brasileira, foram recontadas em publicação recente de Walcyr Carrasco (2014). Nessa obra, encontram-se histórias provenientes do Pentateuco, o primeiro livro da Bíblia hebraica - "Adão, Eva e o jardim do Éden”, “A arca de Noé”, “A torre de Babel”, “José e seus irmãos”, "Esaú e Jacó”, "Moisés, encontrado nas águas" e "A travessia do mar Vermelho" - ao lado de relatos retirados do segmento dedicado aos Profetas, como a trajetória de Sansão, o combate entre Davi e Golias, e a construção do templo de Jerusalém pelo rei Salomão. Os Escritos, última parte da Bíblia hebraica, estão representados pelo episódio em que a rainha Esther assegura a sobrevivência dos hebreus, povo a que pertence, quando eles eram ameaçados pelos persas.

Vários méritos são identificáveis nesse livro de Walcyr Carrasco: a fidelidade aos enredos originais, cujas personagens principais podem ser conhecidas pelo leitores, que, por outro lado, podem ignorar parte dos acontecimentos em que as figuras bíblicas estão envolvidas; e, ao mesmo tempo, uma interpretação muito pessoal dos eventos e, sobretudo, da atuação divina, destituída, nesses relatos, do caráter autoritário e repreensivo que muitas vezes adota nos capítulos da Bíblia hebraica. Na história de Noé, por exemplo, Deus se mostra benévolo e bem-humorado, não a entidade que castiga a quem não a obedece. Por sua vez, no mais popular dos episódios do Pentateuco, o de Adão e Eva no jardim do Éden, o ato transgressivo cometido pelas personagens, após a insinuação malévola da serpente, não é atribuído à fragilidade feminina, mas ao desejo de crescimento intelectual por parte do casal protagonista. Logo, corresponde a um processo de amadurecimento, pelo qual todos passamos, quando nos libertamos da tutela de nossos criadores - sejam deuses, pais ou mestres. Assim, não se verificam moralismo ou doutrinação nessas narrativas, embora muitos ensinamentos, de ordem ética e cultural, possam ser extraídos delas.

\footnotetext{
7 PRESIDÊNCIA DA REPÚBLICA. Constituição da República Federativa do Brasil. Disponível em http://www.planalto.gov.br/ccivil_03/constituicao/ConstituicaoCompilado.htm. Acesso em: 14 set. 2012.
} 
A obra ilustra ainda o modo como é possível lidar com a religião e a fé, sem que seja preciso inculcar uma crença.

A Bíblia é, como se observou, o livro sagrado de muitas religiões monoteístas, especialmente as que predominam no mundo ocidental. Não é preciso ser religioso, ou ser católico, protestante ou judeu, para admirar as histórias narradas em seus vários volumes. Mas Deus - denominado também Senhor ou Jeová - é figura quase onipresente, seja enquanto criador (em “Adão, Eva e o jardim do Éden”), fiscal (“A arca de Noé”, “A torre de Babel”) ou até, digamos, prestador de serviços, como nos episódios protagonizados por Moisés. Em algumas narrativas, é a fé nos atos do Senhor que motiva ou confere segurança às ações humanas, como ocorre respectivamente a Salomão e a José. Assim, Deus pode aparecer de modo menos ou mais visível, estar próximo ou distante, mas nunca deixa de se relacionar aos eventos relatados.

Walcyr Carrasco, portanto, não contradiz o paradigma proposto pela Bíblia, aceito pelas religiões monoteístas do Ocidente. Mas deixa a critério do leitor - criança ou adulto a decisão por acreditar que os fatos narrados aconteceram efetivamente ou são fruto da imaginação humana. A fé e a crença são opções individuais e privadas, e essa liberdade é delegada ao leitor. A obra não as impõe, nem as desacredita, e é esse outro dos méritos do reconto proposto pelo escritor.

A vida do patriarca Moisés será matéria também de livro de Moacyr Scliar. Em Um menino chamado Moisés (SCLIAR, 2004), o escritor narra a história do garoto que, nascido entre os escravos hebreus, é educado pela família do faraó. A obra concentra-se na infância e na juventude da personagem bíblica, procurando mostrar a passagem do jovem à maturidade, associada à descoberta de sua identidade étnica e religiosa. Evitando o proselitismo, Scliar vale-se da trajetória do futuro líder dos judeus, para apresentar questões que motivam a identificação do leitor, também ele na idade de fazer suas escolhas existenciais e optar por um caminho na sociedade.

De formato biográfico é igualmente o livro que Walcyr Carrasco dedica à vida de Jesus Cristo (CARRASCO, 2015).

Jesus é uma das personalidades mais fascinantes da história da humanidade. Seu nascimento, vida, paixão, morte e ressurreição estão cercados de fatos históricos, míticos e lendários. Seus ensinamentos fecundaram uma religião que tomou seu nome - o Cristianismo. E mesmo religiões, como o judaísmo e o islamismo, que não reconhecem Jesus co- 
mo o Messias ou o filho de Deus, aceitam sua existência e atribuem-lhe o papel de profeta, capacitado a anunciar um futuro mundo melhor.

A presença de Jesus é tão forte na cultura ocidental, que mesmo os ateus discutem sua identidade e seus atos, tenham sido esses divinos ou humanos. E não é preciso ser católico, nem mesmo cristão, para aceitar a validade das ideias que propagou, cujos efeitos estendem-se até nossos dias, quase dois mil anos após sua morte. Assim, além de estar associado a uma ou mais confissões religiosas, Jesus é também uma personalidade ligada à ética e aos ideais de mudança na sociedade, apresentando-se como um indivíduo inspirador de ações positivas, bem como de sentimentos bons e saudáveis, livres de preconceitos, e avessos à maldade e à coerção.

Nada mais oportuno, pois, do que conhecer sua vida, do começo ao fim, já que é um exemplo do que se pode aspirar e realizar no nosso tempo, quando assistimos a acontecimentos marcados pela violência, intolerância e intransigência, em tudo contrários aos princípios louvados pelo jovem oriundo da antiga cidade de Nazaré.

Os acontecimentos relacionados à vida de Jesus estão cercados de atos maravilhosos e atitudes corajosas. Ciente de sua missão, expressa no seu nome, que significa, como lembra Walcyr Carrasco em sua narração, “aquele que salva”, o rapaz não teme os adversários, nem se deixa abater quando se depara com reações negativas. Também não o desarmam os preconceitos, as ameaças ou os poderes político e religioso. Pelo contrário, ainda adolescente, desafia e vence os sábios rabinos no templo; adulto, aceita Maria Madalena como seguidora, indiferente ao fato de que a moça até então praticara a prostituição. E prefere dividir as refeições com os humildes, porque esses são puros e generosos, ao contrário dos ricos, que não desejam abrir mão de seus privilégios, mesmo que, em troca, possam alcançar o Paraíso e a vida eterna.

Por isso, é Jesus o Salvador; mas ele é igualmente o Cristo, vale dizer, o "ungido", como explica Carrasco, e o Messias, o Deus aguardado para resgatar a humanidade desde a perda do jardim do Éden por Adão e Eva. É João Batista quem reconhece o atributo messiânico de Jesus, nomeando-o Cristo, e difundindo entre seus adeptos a necessidade de acompanharem o Filho de Deus durante sua trajetória na Terra.

Essa trajetória vem acompanhada de episódios maravilhosos - os milagres, capazes de atestar a divindade de Jesus. Mais importante que os milagres são seus ensinamentos, cristalizados nos sermões transmitidos aos fiéis. Em um dos mais famosos, o Sermão da Volume 17 Número 36 
Montanha, Jesus valoriza os pobres, os simples, os bons, porque a eles caberá o Reino dos Céus. Outro dos ideais expostos por Jesus, conforme se lê na biografia escrita por Walcyr Carrasco, diz respeito à importância da igualdade e da busca de uma sociedade mais justa. Essa justiça será exercida por ocasião do Juízo Final, o Apocalipse, que salvará os bons e condenará para sempre os maus. Embora se possa argumentar que essa experiência paradisíaca ocorrerá apenas no futuro, é importante destacar que os atos que garantirão aquele resultado devem ser praticados no presente, de modo que a sociedade mais justa, em que predominem a igualdade e a fraternidade, deve se evidenciar agora, e não depois. Conforme as ideias de Jesus, não cabe protelar o exercício das boas ações.

Carrasco sai-se bem da tarefa de narrar a vida de Jesus: opta por narrar os acontecimentos em ordem cronológica, desde a anunciação de seu nascimento até a morte e ressurreição, explicando os fatos que, ao leitor contemporâneo, podem parecer incongruentes, como, por exemplo, a circunstância de habitantes oriundos da Galileia, como José e Maria, encontrarem-se em Belém, quando a criança vem à luz; além disso, privilegia o diálogo, o que agiliza o tratamento do enredo; e sumaria o tema dos sermões ou os ensinamentos do Cristo, facilitando a compreensão de seus ideais humanitários.

A produção destinada a crianças e jovens não se restringe a exposição de narrativas vinculadas a personagens dos cultos monoteístas ocidentais, ainda que esses predominem. Moacyr Scliar publicou também ABC do mundo judaico em 2007 (SCLIAR, 2007), e Walcyr Carrasco reuniu as Parábolas da Bíblia em obra lançada em 2015 (CARRASCO, 2015). Mas catálogos atualizados das editoras oferecem farto material bibliográfico, respondendo às necessidades de nosso país, de formação multicultural e diversidade religiosa.

Joel Rufino dos Santos, em A menina que descobriu o segredo da Bahia, de 2014, encontrou excelente solução para apresentar os cultos afrobrasileiros, a cujos mistérios a protagonista, $\mathrm{Vi} \mathrm{Li}$, de origem coreana, precisa ter acesso, a fim de chegar bem sucedida ao final da trama (SANTOS, 2014). Por meio do cotejo entre duas tradições culturais - a brasileira e a asiática -, o escritor expõe não apenas duas distintas e respeitáveis religiões, mas também a relação com as etnias e comunidades que constituem o Brasil contemporâneo.

Pertence também a Joel Rufino dos Santos a coletânea de "histórias de lá e daqui", como indica o subtítulo de Gosto de África, de 1999, dedicado à tradução da mitologia africana que migrou para o Brasil junto com os povos originais daquela região, trazidos para a América na condição de escravos (SANTOS, 1999). A cultura e as crenças de negros e Volume 17

Número 36 
afrodescendentes aparecem igualmente em Num tronco de Iroko vi a iúna cantar, de Erika Balbino, com narrativas e versos paradigmáticos do cotejo entre práticas religiosas e performances que incluem jogos como capoeira, danças e músicas ao som do berimbau, instrumento característico da cultura popular (BALBINO, 2014).

Não menos importante é a compreensão dos mitos e concepções religiosas indígenas, que têm em Daniel Munduruku um de seus principais expoentes. Histórias que eu ouvi e gosto de contar e Foi vovó que disse são dois exemplos de coletâneas de narrativas que traduzem o imaginário religioso indígena, associado à sua expressão por meio de relatos orais transmitidos dos mais idosos aos mais jovens, conforme uma corrente etária que assegura a tradição e seus modos especiais de comunicação (MUNDURUKU, 2004; MUNDURUKU, 2014). ${ }^{8}$

No Brasil do novo milênio, convivem, segundo o último censo do Instituto Brasileiro de Geografia e Estatística (IBGE), mais de 25 religiões ou crenças, ${ }^{9}$ contando-se entre as mais numerosas a Igreja Católica Apostólica Romana e a Igreja Luterana, além dos cultos evangélicos e pentecostais. Nesse horizonte múltiplo, há lugar para adventistas, mórmons, budistas, umbandistas, islâmicos, judeus, bem como seguidores da fé Bahá'í, hare krishna e hinduísta, para citarmos algumas das vertentes religiosas identificadas pela pesquisa demográfica.

Nem todas essas vertentes contam hoje com numerosa produção infantojuvenil. Malba Tahan, pseudônimo de Julio Cesar de Mello e Souza, coletou o acervo lendário árabe em Contos das Mil e uma noites, e, em O homem que calculava, incorporou à literatura para jovens o universo cultural do Oriente, sem, entretanto, dedicar-se particularmente a tópicos vinculados a crença islâmica. Mas são promissores os caminhos a serem adotados por escritores que se debruçarem sobre temas religiosos, pois o que se espera da literatura é que, em vez de partidarismos, ela expresse o sentimento de humanidade e irmandade que, de modo menos ou mais evidente, está presente nas distintas confissões.

\footnotetext{
${ }^{8}$ MUNDURUKU, Daniel. Histórias que eu ouvi e gosto de contar. São Paulo: Callis, 2004. MUNDURUKU, Daniel. Foi vovó que disse. Porto Alegre: Edelbra, 2014.

${ }^{9}$ Cf. http://www.suapesquisa.com/religiaosociais/religioes_brasil.htm. Acesso em: 20 nov. 2015. 


\section{REFERÊNCIAS}

ASSMANN, Jan. Moses the Egiptian. The Memory of Egypt in Western Monotheism. Cambridge, Mass; London: Harvard University Press, 1998.

BALBINO, Erika. Num tronco de Iroko vi a iúna cantar. São Paulo: Peirópolis, 2014. BERNSTEIN, Richard J. Freud e o legado de Moisés. Trad. Laura Rumchinsky. Rio de Janeiro: Imago, 2000.

BRASIL. Ministério da Educação. Base Nacional Comum Curricular. Proposta preliminar. 2. ed. revista. Brasília: Ministério de Educação, 2016.

CARRASCO, Walcyr. A vida de Jesus. São Paulo: Moderna, 2015.

CARRASCO, Walcyr. Histórias da Bíblia. São Paulo: Moderna, 2014.

CARRASCO, Walcyr. Parábolas da Bíblia. São Paulo: Moderna, 2015.

FREUD, Sigmund. Moisés e o monoteísmo. Trad. Maria Aparecida Moraes Rego. Rio de Janeiro: Imago, 2001.

FREUD, Sigmund. O futuro de uma ilusão. Trad. Jayme Salomão. Rio de Janeiro: Imago, 1996. (Edição Standard Brasileira das Obras Psicológicas Completas de Sigmund Freud, v. XXI).

FREUD, Sigmund. O mal-estar na civilização. Trad. Jayme Salomão. Rio de Janeiro: Imago, 1996a. (Edição Standard Brasileira das Obras Psicológicas Completas de Sigmund Freud, v. XXI).

FREUD, Sigmund. Tótem y tabú. Trad. Luis López-Ballesteros y de Torres. Madri: Alianza, 1970.

http://www.suapesquisa.com/religiaosociais/religioes_brasil.htm. Acesso em: 20 nov. 2015. MIGNOLO, Walter. The Darker Side of the Renaissance. Literacy, Territoriality, and Colonization. 4. ed. Ann Arbor: The University of Michigan Press, 1998.

MOACYR, Primitivo. A instrução e as províncias. (Subsídios para a história da educação no Brasil). 1835-1889. São Paulo: Nacional, 1939. V. 2.

MUNDURUKU, Daniel. Histórias que eu ouvi e gosto de contar. São Paulo: Callis, 2004.

MUNDURUKU, Daniel. Foi vovó que disse. Porto Alegre: Edelbra, 2014.

PRESIDÊNCIA DA REPÚBLICA. Constituição da República Federativa do Brasil. Disponível em http://www.planalto.gov.br/ccivil_03/constituicao/ConstituicaoCompilado.htm. Acesso em: 14 set. 2012.

RIBEIRO, Darcy. Uirá sai à procura de Deus: ensaios de etnologia e indigenismo. Rio de Janeiro: Paz e Terra, 1980.

ROSSI, Marcelo. Agapinho. Ágape para crianças. São Paulo: Globo, 2012.

SANTOS, Joel Rufino dos. Gosto de África. Histórias de lá e daqui. São Paulo: Global, 1999.

SANTOS, Joel Rufino dos. A menina que descobriu o segredo da Bahia. Rio de Janeiro: Rovelle, 2014.

SCLIAR, Moacyr. Um menino chamado Moisés. São Paulo: Ática, 2004.

SCLIAR, Moacyr. ABC do mundo judaico. São Paulo: SM, 2007.

TAMBARA, Elomar. Livros de leitura nas escolas de ensino primário no século XIX no Brasil. Disponível em: https://www.google.com.br/?gfe_rd=cr\&ei=vjNXVuucKoOq8weim $\mathrm{J}$-gCQ\#q=TAMBARA\%2C+Elomar.+Livros+de+leitura+nas+escolas+de+ensino+prim \%C3\%A1rio+no+s\%C3\%A9culo+XIX+no+Brasil. Acesso em: 21 jan. 2009. 


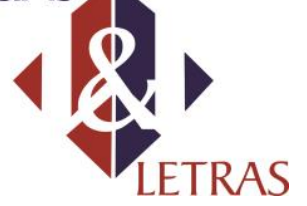

YERUSHALMI, Yosef Hayim. El Moises de Freud. Judaismo terminable e interminable. Trad. Horacio Pons. Buenos Aires: Nueva Vision, 1996.

Data de recebimento: 29/11/2016

Data de aprovação: 29/11/2016 